Article

\title{
The Commodification, Spatialization and Structuration of Social Media in the Indonesian Cyber Media News
}

\author{
Muslikhin Muslikhin ${ }^{1, *}$, Deddy Mulyana ${ }^{1}$, Dadang Rahmat Hidayat ${ }^{1}$ and Prahastiwi Utari ${ }^{2}$ \\ ${ }^{1}$ Faculty of Communication Sciences, Padjadjaran University, Jawa Barat 45363, Indonesia; \\ E-Mails: muslikhin18001@mail.unpad.ac.id (M.M.), deddymulyana@unpad.ac.id (D.M.), \\ dadang.rahmat@unpad.ac.id (D.R.H.) \\ 2 Department of Communication Science, Sebelas Maret University, Jawa Tengah 57126, Indonesia; \\ E-Mail: prahastiwi@staff.uns.ac.id \\ * Corresponding author
}

Submitted: 15 October 2020 | Accepted: 17 November 2020 | Published: 6 April 2021

\begin{abstract}
This research aims to uncover the commodification, spatialization, and structuration of Social Media within Cyber Media News in Indonesia. A critical perspective was used to conduct the study using a case study method. Through the use of Vincent Mosco political economy theory of media, the authors conclude that Tribunnews.com, the cyber media news, and the object of this research, makes social media a commodity and a content distribution channel, by involving all parts of the newsroom to utilize social media (structuration). The commodification of content is carried out by making information on social media an initial source for news production. Audience commodification by using the followers of social media accounts as a source of income. This was achieved by offering social media accounts to the advertisers to put their advertisement on official social media accounts. Through the use of social media, journalists are used by Tribunnews.com for profit. Utilization is carried out by distributing journalists' work to social media, and to other cyber media news included in the media group-without providing additional wages. Spatialization was carried out by using social media as a means of news distribution or amplification. The goal is to reach readers who mostly get their information through the Internet, including through smartphones and social media. Structuration achieved through the formation of a team dedicated to managing the use of social media in the production and distribution of news.
\end{abstract}

\section{Keywords}

commodification; distribution; followers; Indonesia; journalism; news; social media

\section{Issue}

This article is part of the issue "Critical Theory in a Digital Media Age: Ways Forward" edited by Robert E. Gutsche, Jr. (Lancaster University, UK).

(C) 2021 by the authors; licensee Cogitatio (Lisbon, Portugal). This article is licensed under a Creative Commons Attribution 4.0 International License (CC BY).

\section{Introduction}

This study aims to reveal the commodification, spatialization and structuration of social media carried out by cyber media news in Indonesia. Research is based on the phenomenon that the presence of social media has influenced the work process of journalism (Nasrullah, 2015. p. 155). Bossio explained that social media has changed the process of production, distribution and consumption of news (Bossio, 2017, p. 70).
Agus Sudibyo called social media a 'frenemy,' a friend and an enemy, or a friend as well as an opponent of press or journalistic publishing. Nikos Smyrnaios (2015), as cited by Sudibyo, said that there was a contest between social media and major media in the form of cooperation and competition (Sudibyo, 2019, p. 4). It is known as a cooperative friend because social media has recently provided a lot of information which has facilitated the production of news and has also become a channel for disseminating information from major media. 
Meanwhile, it is known to compete with and oppose, because social media is essentially a media company that makes it living from the process of selling information or the commodification of information, as do the major media companies, including cyber media news.

The Cyber media news outlet under study here is Tribunnews.com. There are many reasons for making Tribunnews.com an object of research. First, when this research was conducted, Tribunnews.com was ranked as the top cyber media news outlet in Indonesia, based on Alexa ranking. Currently, Tribunnews.com, in terms of pageview visitors, is in second place in the Alexa ranking. But in terms of the percentage of search traffic, Tribunnews.com comes first with $61.60 \%$ (Alexa, 2020). Second, Tribunnews.com is one of the cyber media news in Indonesia that has viewed social media as a friend since its inception on March 22, 2010: "Since Tribunnews.com was founded, I have seen social media as the most important part of the overall, the strategy of Tribunnews.com" (Interview with informant 1, on November 11, 2019). Third, Tribunnews.com was the largest cyber news media in Indonesia, having a network across 24 cities throughout Indonesia.

Research on social media influencing journalism, from gathering, production, distribution, and consumption of news has been conducted by previous researchers (Brandtzaeg, Følstad, \& Domínguez, 2017, pp. 1-21; Djerf-Pierre, Lindgren, \& Budinski, 2019, pp. 235-247; Ferrucci, 2018, pp. 1-12; Jukes, 2019, pp. 248-258; Safori, 2018, pp. 148-162; Zakaria, \& Razak, 2018, pp. 29-49). However, research on the cyber news media who engage in the commodification, spatialization, and structuration of social media, especially in Indonesia, has not been conducted by many researchers to date. Research on the commodification carried out by the media in Indonesia generally focuses on certain issues or topics, such as religion (Anggraeni, Wuryanta, \& Wenats, 2020, pp. 61-73). This is why the research presented here different to previous research.

There are many reasons why research using the political economy theory of media in recent decades has become increasingly relevant and important. This is in line with the trend in the media business that takes advantage of the development of communication technology, especially that relating to social media. First, there is a growing concentration of media around the world with more concentrated power in the hands of a few and a tendency to combine the hardware and software industries. The media industry includes social media which is controlled by a large group of media. Second, there is a growing global information economy that involves increasing convergence between telecommunications and broadcasting. Third, the reduction of control of the mass media and telecommunications in the public sector due to deregulation, privatization, and liberal policies. Finally, there are problems with the development of information inequality, the digital divide (Ibrahim \& Akhmad, 2014, pp. 15-16).
Research on the commodification, spatialization, and structuration of social media by cyber media news is important for two main reasons. First, the findings in this study are expected to become a comprehensive reference in the management of the cyber media news industry in Indonesia on how to use social media for managing cyber media news. Besides, the factual findings of this research can be used as reference material and study in the development of learning about journalism in the era of social media. The research questions are:

RQ1: How was social media commodified by Tribunnews.com?

RQ2: How was social media spatialized by Tribunnews.com?

RQ3: How does Tribunnews.com conduct structuration in utilizing social media in its journalistic work process?

\section{Study of the Political Economy of Media in the Era of Social Media}

The political economy theory of media is defined as a social criticism approach that focuses on the relationship between the economic structure and dynamics of the media industry and the ideological content of the media. According to this theory, media institutions including social media were considered part of an economic system that was closely related to the political system (McQuail, 2011, pp. 245-247).

Social media has now become a new force called the fifth pillar of democracy, after the executive, legislative, judiciary, and press freedom. The birth of this fifth pillar was due to public disappointment with the four other pillars of democracy (Syah, 2014, p. 14). Social media is not just a platform for sharing text or video, but in principle, it is a media company the same as any other which aim to make a profit. Social media as a media company was also the object of media economy studies.

Vincent Mosco's media studies are related to issues around the political economy of the media, problems in the labour sector in the media industry, as well as studies of the development and presence of new media. Mosco defined political economy as "the study of relations, particularly the power relations, that mutually constitutes the production, distribution, and consumption of resources" (2009, p. 2). Mosco divided the political economy into three parts: commodification, spatialization, and structuration (2009, pp. 11-17).

Commodification is the process of changing or converting the value of goods into exchange rates. There are three types of commodification in the media industry, namely content commodification, audience commodification, and the commodification of media workers (Mosco, 2009, pp. 129-140).

Spatialization is related to the extent to which the media can present their products to an audience within 
space and time constraints. Structuration is described as the process by which social structures are upheld by social agents which later become part of the structure and act to serve other parts. This structuration explains the relationship of ideas between community agents, social processes, and social practices (Mosco, 2009, pp. 158, 189).

The political economy of media from Mosco remains relevant as a basis for exploring the relationship between cyber news media and social media. Social media is accessed by $85 \%$ of Internet users in Indonesia (Pertiwi, 2019) and has been used as a commodity by cyber media news for profit. Apart from being a commodity, social media is also used as a distribution of content produced by cyber media news to reach a wider audience (spatialization). Journalists who form part of cyber media news must understand the dynamics of social media to support their journalistic work processes (structuration).

\section{Sources of Income for Cyber Media News in Indonesia}

At the end of 2019 , there were 47,000 cyber media news outlets in Indonesia, of which only 2,700 (5.7\%) had been verified by the Press Council-the remaining $94.3 \%$ were unverified (AMSI, 2019). The number of cyber media news creates intense competition, including competition for traffic. Traffic is the activity on one page of your site that results from visits on that page: The longer the site page is visited, and the more visitors are active on it, the higher traffic will be. The purpose of traffic for online media is to acquire advertising revenue, which is the main source of income from cyber media news in Indonesia (Margianto \& Syaefullah, 2014, p. 29)

Marina Korobka explained there are six sources of income for cyber media news: paid articles, sponsored links, paywalls, the sharing of experts' opinions, PPC (AdSense) networks, and banner ads. Paid articles, also known as advertorials, are articles in cyber media news that are sponsored by a product. The sponsored links that appear in such articles provide sponsorship for the publication of the article. A paywall is a subscription system that attracts payments from users or readers to allow them to access or read certain content in full. Numerous cyber media news apply such a paywall system, including The Washington Post in the US and Kompas in Indonesia. PPC network and Google AdSense are advertisements provided by Google and installed on web pages in collaboration with Google. The owner of cyber media news only provides a place for Google's clients to advertise. Banner ads are advertisements placed directly by advertisers on news sites (Korobka, 2020).

\section{Methodology}

This study used a qualitative approach with a critical paradigm. The method used was a case study.
According to Rob VanWynsberghe and Samia Khan, a critical paradigm can use the case study method because a case study is a trans-paradigmatic research method that is relevant to all research paradigms both positivistic, post-positivistic, critical, and constructivist or interpretive. Besides being trans-paradigmatic, a case study is also transdisciplinary which seeks to describe in full, detailed evidence of phenomena that have been collected in various forms, such as events, concepts, programs, and processes (VanWynsberghe \& Khan, 2007, pp. 80-94).

Stake (2009, p. 301) divided case studies into three types: intrinsic case studies, instrumental case studies, and collective case studies. Yin stated that a case study should be carried out when the researcher wants to do detailed and complete research on an individual or a social unit during a certain period which involves the researcher in a deeper investigation and a thorough examination of the person's behavior or observed cases. A case study is a more suitable strategy if the main question of the study regards 'how' and 'why.' With the choice of these questions, the expected answers from the results of the study may not seem very broad, but they are discussed in great detail (Yin, 2018, p. 41).

Based on the characteristics of this case study, the research requires a case-study approach. The case raised in this study was the process of journalistic work carried out by Tribunnews.com as they made use of social media. This research aimed to answer the question of how Tribunnews.com carries out the commodification, spatialization, and structuring of social media in the process of producing news for their website.

Data collection in this study was carried out in two ways. First, semi-structured interviews with nine informants managing Tribunnews.com, numbered 1 to 9 . Informants were selected based on their duties and responsibilities in utilizing social media at Tribunnews.com. Second, utilizing documents such as editorial meeting notes, lists of proposed reports, and news texts related to social media published on Tribunnews.com. Data were collected from November 2019 to March 2020 at the Tribunnews.com Newsroom Jakarta and Solo, Central Java, Indonesia.

The data analysis technique in this study followed the stages of analysis developed by Creswell. First, the data from interviews with informants and data on the use of social media in publications on Tribunnews.com was processed and prepared for analysis. Second, the data was all read before, third, being coded manually. The code provided was then adjusted to the information we wanted to find: commodification of content, audience, workers, distribution channels, and structuration. Fourth, the coding was applied to describe the categories and themes to be analysed. Fifth, this showed how the description and theme should be restated in a qualitative narrative/report. Sixth, the interpretation of the data was carried out. The validity of the data was tested by triangulating sources, triangulating data and methods, 
checking members, and making rich, detailed descriptions of research results (Creswell, 2016, pp. 264-268).

The reliability procedure used in this study also followed a procedure developed by Creswell: We checked the results of the informants' transcripts to ensure there were no errors in the transcription process. We ensured that there were no ambiguous meanings in the code in the coding process, and we asked other coders to code existing data. The coding results from other coders were then compared with the coding results from the researchers. If there were differences in coding, a discussion was held, so that an intercoder agreement could be reached between the researcher and other coders (Creswell, 2016, p. 272).

\section{Result}

\subsection{Commodification of Content: Social Media as an Initial Source of News}

Content commodification was carried out by Tribunnews.com by utilizing social media content as a source of initial information to produce published news. All popular social media in Indonesia, Twitter, Facebook, Instagram, YouTube, and Tik Tok are all used as initial information sources for producing news, except WhatsApp and LINE. WhatsApp and LINE are not used as initial information sources because of the large amount of misinformation and disinformation information that is prevalent in the two social media based on the conversation or chat (Interview with informant 2, on February 19, 2020).

According to informant 2, the criteria for social media content that were used as the initial source of information for the news were whether an item is viral, a trending topic, or is something sought out by many readers, whether it is unique, or contains information about celebrities, official government statements, and policymakers. Besides, the information must not contain mystical elements, sadism, sexual harassment, expressions of hatred, expressions of ethnicity, religion, race, or anything highlighting intergroup differences.

One day, Tribunnews.com produces an average of 300 news stories sourced from social media. This amount is equivalent to $30 \%$ of the total news generated by Tribunnews.com in one day-as many as one thousand articles (Interviews with informants 2 and 1 ). The informant's explanation is in line with the results of observations for two months, June and July 2020 regarding the news published on Tribunnews.com. The social media content used as a news source in Tribunnews.com takes the form of photos for news illustrations, and text for references in writing news.

There are many reasons why Tribunnews.com makes social media content a commodity. First, information on social media is rapidly changing and highly diverse. The speed and variety of information are then used as initial information which is then processed into news
(Nasrullah, 2015, pp. 156-160). Second, If the news on Tribunnews.com is not made in line with the conversation or trending topic on social media, the site will be left by those readers, who previously received their information from social media (Interview with informant 1 ). Even though readers may receive information from social media, they still need cyber media news as a means of checking the veracity of information on social media (Interview with informant 2). This is in line with the role of journalism in the era of social media, namely as an authenticator (Kovach, \& Rosenstiel, 2012, p. 184).

Third, there is a change in the behavior of news sources. Currently, news sources such as state officials and public figures upload activities, statements, and attitudes regarding issues of interest, to social media accounts such as YouTube, Instagram, and Twitter. Information on the informants' social media accounts, after being verified for authenticity, is used as part of confirmation and verification (Kovach, \& Rosenstiel, 2003, p. 6).

Fourth, there is a change in the use of media by readers, especially among generation $Y$ (millennial) and generation $Z$ (Interview with informant 2). The two generations are highly dependent on smartphones and are highly active on social media. According to data from socialmediaweek.org, millennials spend an average of six to seven hours per week on social media, while generation $Z, 44 \%$ of them check their social media accounts on an hourly basis ("Mengenal Karakter," 2018). According to the Chairman of the Indonesian Press Council (2016-2019), Yosef Adi Prasetyo, Generation Y and $Z$ follow the developments taking place around them through social media (Prasetyo, 2018).

Fifth, social media conversations which become trending topics, if they are valuable and newsworthy, will be reported by Tribunnews.com (Interview with informant 4, on March 12, 2020). Adornato (2018, pp. 20-21) and Alejandro (2010, pp. 14-15) explained that social media has changed the process of finding news or newsgathering. Before the editorial meeting, the editor will read social media, to find out what discussions are popular on social media.

What Tribunnews.com has done, in the view of Yosef Adi Prasetyo (Chairman of the Press Council 2016-2019), is logical given the development of communication technology, especially smartphones which are widely used to access social media. The media must adapt if they do not want to be abandoned by their readers (Prasetyo, 2018).

\subsection{Audience Commodification: Social Media as a Means of Making Money or Monetizing}

The commodification of the audience is achieved by Tribunnews.com by monetizing its social media account followers. Tribunnews.com has a range of accounts on a popular social media platform in Indonesia: on YouTube under the name Tribunnews.com with 2,44 million subscribers, as of April 5, 2020; on Instagram, with the 
name @tribunnews, it has many as 982,000 followers; on Twitter with an account called @tribunnews, it has as many as 927,000 followers; and on Facebook, with the name Tribunnews.com, it was followed by 8,2 million people and liked by 8,3 million. Monetization is achieved by offering followers of each of these social media accounts to advertisers. Advertisers can place an advertisement on all social media accounts belonging to Tribunnews.com by paying a fixed amount of money.

There are two forms of monetizing of social media audiences carried out by Tribunnews.com. First, as stated by informant 2 , is direct selling: marketing in which Tribunnews.com offers advertisers direct placement of ads on Tribunnews.com social media accounts. Second, profit sharing with social media platform companies, using Tribunnews.com allowing programmatic advertising managed by social media platform providers:

Facebook is also looking for companies that want to put an advertisement on them. We placed and entered their environment. We entered their ecosystem. They put advertisements; it is up to them. Later, the profit will be shared by those who control the Facebook. (Interview with informant 1)

\subsection{Commodification of Journalists by Tribunnews.com Company and Social Media Companies}

The use of social media had resulted in the commodification of journalists by Tribunnews.com and social media companies. In practice, journalists not only work for Tribunnews.com but also indirectly work for social media companies such as Facebook, Twitter, Instagram, LINE, and YouTube-the social media platforms where Tribunnews.com has accounts. The reason is that the content produced by journalists is not only uploaded on the Tribunnews.com but also shared on social media accounts. From the uploaded content, both Tribunnews.com and social media benefit materially. However, journalists only receive their salary from Tribunnews.com; they get nothing from social media companies.

Tribunnews.com management argued that the distribution of journalists' work content to social media is normal, as part of media convergence, to get more readers. This is what in the commodification of workers is called naturalization. Naturalization is an effort by a company that considers normal, ordinary, and reasonable social relations or relations between labour and capital, and although this is exploitative, the workers accept it without thinking (Pratopo, 2017).

The commodification of journalists was achieved via several means by Tribunnews.com. First, disseminating content produced by journalists to other cyber media news websites located in the Tribunnews.com network in 24 cities throughout Indonesia, and other cyber media news within the Kompas Gramedia Group. Although it is distributed to other cyber media news, journalists do not receive any additional wages. Second, it requires journal- ists to produce content in the form of text, photos, and videos. Each day, a journalist has a content production target; if not achieved, it will affect the assessment of their performance.

According to informant 1 , the distribution of Tribunnews.com content to other media which is still in the same Kompas Gramedia Group is not exploitation, but rather an act of efficiently managing content. The reason is that the journalists' content actually belongs to Tribunnews.com, not the journalists. Such content can therefore be distributed to all cyber media news within Kompas Gramedia Group's cyber media network. Thus, other cyber media news do not need to pay to produce their content, as they are able to acquire it from Tribunnews.com at no cost.

Meanwhile, informant 2 explained that journalists who work at Tribunnews.com must have a range of skills and ability to multitask: In the era of media convergence, journalists must be able to make news in the form of text, photos, and video:

As the field reporters, they are now multitalented. They must be able to type quickly, take photos and videos, although taking videos is not as active as making news. First, after getting the news, they go to the office to make the news. Then we change it to real-time. News can be directly written and sent in real-time. This is a long process when we were first introduced to reporters. After that, the road is already established and there are new demands. They must make videos. (Interviews with informant 2)

Media owners use efficiency and multitasking to justify the commodification of journalists. Efficiency is a naturalization in the process of journalist commodification, which is then accepted as a natural state of affairs. Multitasking is a way for companies to ensure their workers are highly productive-and more likely to bring greater profit to the company. In order not to create an impression of exploitation, a false belief has been constructed that multi-tasking is a must for journalists in the current era of media convergence.

\subsection{Spatialization: Social Media as a Channel for Content Distribution or Amplification}

Tribunnews.com makes social media the primary means for the distribution and amplification of content to ensure it reaches sufficient numbers of readers. This method is done to reach readers who now consume the majority of their information consumption via the Internet, through smartphones and social media (Adornato, 2018, pp. 25-27). According to a survey conducted by DS Research in 2017, about the behavior of the Indonesian Internet community's news consumption through social media, Facebook was used by $70.85 \%$ of the Internet community in Indonesia to search for new news, followed by LINE Today, with 
50.64\% (DailySocialID, 2017). DS Research's research is in line with research conducted by the Indonesian Research Institute, or LIPI, stating that $60.6 \%$ of generation $\mathrm{Z}$ access political news through social media (Setyowati, 2018).

According to informant 1, when Tribunnews.com was first established on March 22, 2010, the best social media for content distribution was Twitter. However, because online media already had strong competitors on Twitter, Tribunnews.com chose Facebook as for its content distribution. The reason is that if they had used Twitter, they would not have been able to compete with those outlets whose followers had reached tens of millions, while Tribunnews.com had only just got started. Besides, Twitter is more widely used by the Internet community in Jakarta and Bandung. Outside these two cities, Facebook is more widely used. Besides, many Tribune networks are in the regions. Although Facebook is the main choice for content distribution, Tribunnews.com does not neglect other social media platforms for content distribution. Twitter, Instagram, YouTube, and LINE are also used for content distribution:

Twitter is a big city phenomenon such as Jakarta and Bandung at that time. It is very strong. However, outside of these two cities, Facebook was the one that was growing very rapidly. There are many Tribune Networks in the regions, so that, those two reasons explain why now, strategically we put Facebook as an important part of our distribution channel. (Interview with informant 1)

According to informants 2 and 8 , not all content on Tribunnews.com is distributed through social media, but only content that has high traffic, lots of readers, is actual news and is much sought after by the readers. To identify which content is currently high in traffic, most sought after, and read by people, Google Analytics tools, Google Trends, and trending topics on Twitter were used: "So, we open google analytics. How about the traffic in the content or overview. If the overview is in the top 10 highest on Facebook, or throughout Tribunnews.com, then we choose to share it" (Interview with informant 8, on March 11, 2020).

The time for the distribution of content to social media varies, depending on the platform. According to informant number 8, for Facebook, content is uploaded every 10 to 15 minutes. There is no set time to upload content to Twitter. Content can be uploaded at any time, as long as it is new, actual, interesting, and has high attention from readers.

Meanwhile, Instagram follows the division of time between prime time and non-prime time. Tribunnews.com considers that the prime times to share content to Instagram is 7am-10am and $4 \mathrm{pm}-5 \mathrm{pm}$. During these prime times, Tribunnews.com will upload content to Instagram much more frequently, as often as possible.
Content shared on social media takes the form of text, videos, and links for readers to enter content on Tribunnews.com (Interview with informant 8). As for YouTube, according to the platform, everything is in the form of video, as of February 6, 2021, 79,143 videos had been uploaded (Tribunnews.com, 2021).

Informant 8 explained that the distribution of content to LINE is only done on weekends, Saturdays, and Sundays. According to informant 3, this step was taken because there was a policy change from LINE in early 2019 , which limited the amount of content shared to LINE to only 20-25 items per month. Prior to this policy change, Tribunnews.com content was uploaded daily to LINE, in the same pattern as Facebook (Interview with informants 3 and 8 on March 11, 2020).

\subsection{Making a Special Social Media Team}

The presence of social media has influenced the news production process. Journalists must pay attention and observe the dynamics that occur on social media, to be used as news writing material (Bossio, 2017, pp. 67-69). Information on social media is used optimally to support news production-as Tribunnews.com does.

To maximize the use of social media in the newsroom, Tribunnews.com formed a section to manage social media. According to informant 4, the Tribunnews.com social media teams were made up of 48 people: three editors, 16 uploaders, 28 reporters, and one assistant manager (Interview with informant 4). The task of the social media team is to create content by utilizing secondary sources such as social media, television programs uploaded on YouTube, distributing content on websites, and social media accounts.

Meanwhile, informant 2 explained that, in addition to forming a special social media team, Tribunnews.com management also required all members of the editorial team outside the special social media team, to utilize social media in the process of finding news or gathering news. This enables them to determine the issues which are active and getting the attention of netizens. Besides, at this time most news sources from government agencies, state officials, and public figures such as celebrities were using social media to convey their attitudes and views on issues or problems. This method is very helpful in the process of confirming a problem because there is no need to do a direct interview with a news source, one can simply take the information from their official social media account (interview with informant 2).

Tribunnews.com's step requiring all members of the editorial team to use social media is part of the process of involving all agents within the organization's newsroom: As explained by Mosco (2009), they structure the agents involved to be part of the structure and to serve other parts. The editorial members, specifically the social media section and those who work alongside them, all act to serve the interests of the company, which is looking for profit by making the most of social media. 


\section{Conclusion}

This research concluded that Tribunnews.com has exploited social media by making it a commodity, a content distribution channel or spatialization, and by involving all sections or agents of Tribunnews.com in the usage of social media or structuration. The commodification of content is carried out by making information available on social media as the initial source for producing news or content uploaded to Tribunnews.com. As much as 30\% of the content on Tribunnews.com sources originally comes from social media.

In using social media by Tribunnews.com, journalists are exploited by online media companies and social media companies as their work is distributed to other online media in a media group Kompas Gramedia Group without providing them any recompense. Besides, the commodification of workers is carried out by requiring journalists at Tribunnews.com to produce a certain amount of content in the form of text, photos, and videos. Unmet targets negatively affect the assessment of journalists' performance.

Spatialization is carried out by using social media as a means for the distribution or amplification of Tribunnews.com content. The goal is to reach those readers who nowadays consume the majority of their information consumption via the Internet, through smartphones and social media.

Structuration is carried out through the formation of a team to manage the use of social media in the production and distribution of news, as well as through the requirement that all members of the editorial team use social media in the process of producing news uploaded on Tribunnews.com.

\section{Acknowledgments}

Researchers would like to thank Bina Nusantara University for providing full scholarships to researchers to study at the Communication Science Doctoral Program, Padjajaran University Bandung, Indonesia. Researchers also thanked the journalists of Tribunnews.com where this research was conducted.

\section{Conflict of Interests}

The authors declare no conflict of interests.

\section{References}

Adornato, A. (2018). Mobile and social media journalism: A practical guide. London: Sage Publication.

Alejandro, J. (2010). Journalism in the age of social media. London: Reuters Institute.

Alexa. (2020, March 29). Top site in Indonesia. Alexa. Retrieved from https://www.alexa.com/topsites/ countries/ID

AMSI. (2019, April 6). Dari 47 Ribu, Baru 2.700 Media
Online Terverifikasi Dewan Pers [Of the 47 thousand, only 2,700 online media have been verified by the Press Council]. AMSI. Retrieved from https://www. amsi.or.id/dari-47-ribu-baru-2-700-media-onlineterverifikasi-dewan-pers/\#: :text=\%E2\%80\%9CB eberapa\%20waktu\%20lalu\%20jumlah\%20media, \%2F4\%2F19)\%20mala

Anggraeni, A., Wuryanta, E., \& Wenats, W. (2020, July 2). Industri Religi Pada Media Online: Penerapan Teori Ekonomi Politik Vincent Moscow (Komodifikasi) Pada Pemberitaan Umroh di Tribunnews.com [The religious industry in online media: The application of Vincent Moscow's political economy theory(commodification) to Umrah reporting on Tribunnews.com]. Communications, 2(2), 61-73.

Bossio, D. (2017). Journalism and social media: Practitioners, organisations and institutions. Cham: Palgrave Macmillan.

Brandtzaeg, P. B., Følstad, A., \& Domínguez, M. A. C. (2017). How journalists and social media users perceive online fact-checking and verification services. Journalism Practice, 12(9), 1-21.

Creswell, J. W. (2016). Research Design: Pendekatan Metode Kualitatif, Kuantitatif, dan Campuran (Terjemahan) [Research design: Qualitative, quantitative, and mixed method approaches]. Yogyakarta: Pustaka Pelajar.

DailySocialID. (2017). Indonesia online news reading habits. Jakarta: DailySocialID.

Djerf-Pierre, M., Lindgren, M., \& Budinski, M. A. (2019). The role of journalism on YouTube: Audience engagement with 'superbug' reporting. Media and Communication, 7(1), 235-247.

Ferrucci, P. (2018). Networked social media's impact on news production in digital newsrooms. Newspaper Research Journal. https://doi.org/10.1177/ 0739532918761069

Ibrahim, I. S., \& Akhmad, B. A. (2014). Komunikasi dan Komodifikasi: Mengkaji Media dan Budaya dalam Dinamika Globalisasi [Communication and commodification: Examining media and culture in the dynamics of globalization]. Jakarta: Obor.

Jukes, S. (2019). Crossing the Line between news and the business of news: Exploring journalists' use of Twitter. Media and Communication, 7(1), 248-258.

Korobka, M. (2020, November 15). Top five best ways to monetize a news website. Light. Retrieved from https://light-it.net/blog/top-five-best-ways-tomonetize-a-news-website

Kovach, B., \& Rosenstiel, T. (2003). Sembilan Elemen Jurnalisme [The Nine Elements of Journalism]. Jakarta: Pantau.

Kovach, B., \& Rosenstiel, T. (2012). Blur, Bagaimana Mengetahui Kebenaran Di Era Banjir Informasi [Blur, how to know the truth in the information flood age]. Jakarta: Dewan Pers.

Margianto, J. H., \& Syaefullah, A. (2014). Media Online, Pembaca, Laba dan Etika [Online media, readers, 
profits and ethics]. Jakarta: Aliansi Jurnalis Independen (AJI) Indonesia.

McQuail, D. (2011). Teori Komunikasi Mass [Mass communication theory]. Jakarta: Salemba Humanika.

Mengenal Karakter 5 Generasi: Baby Boomers, X, Y, Z dan Alpha [Get to know the characters of 5 generations: Baby Boomers, X, Y, Z and Alpha]. (2018, October 30). Kumparan. Retrieved from https://kumparan.com/ kumparansains/mengenal-karakter-5-generasi-baby -boomers-x-y-z-dan-alpha-1540826163812714870

Mosco, V. (2009). The political economy of communication (2nd ed.). London: SAGE.

Nasrullah, R. (2015). Media Sosial: Perspektif Komunikasi, Budaya dan Sosioteknologi [Social media: Communication, culture and socio technology perspectives]. Bandung: Sembiosa Rekatama Media.

Pertiwi, W. K. (2019, February 5). Facebook Jadi Medsos Paling Digemari di Indonesia [Facebook becomes the most popular social media in Indonesia]. Kompas. Retrieved from https://tekno.kompas.com/read/ 2019/02/05/11080097/facebook-jadi-medsospaling-digemari-di-indonesia

Prasetyo, Y. (2018). Pers dan Tantangan Teknologi [The press and technological challenges]. Jakarta: Dewan Pers. Retrieved from https://dewanpers.or.id/ assets/ebook/buletin/1901220126_201810_ETIKA_Edisi_Oktober_2018.pdf

Pratopo, W. M. (2017). Komodifikasi Wartawan di Era Konvergensi: Studi Kasus Tempo [Commodification of journalists in the convergence era: A case study of tempo]. Jurnal Komunikasi Indonesia, VI(2), 129-138.
Safori, A. O. (2018). Social media's impact on a journalist's role. Journal of Science Education, 19(1), 1-15.

Setyowati, D. (2018, July 18). LIPI: 60\% Anak Muda Akses Berita Politik Lewat Media Sosial [LIPI: $60 \%$ of young people access political news through social media]. Katadata. Retrieved from https://katadata.co.id/ pingitaria/digital/5e9a55e40ff3a/lipi-60-anakmuda-akses-berita-politik-lewat-media-sosial

Stake, R. E. (2009). Studi Kasus [Case study]. In N. K. Denzin (Ed.), Handbook of qualitative research (pp. 299-315). Yogyakarta: Pustaka Pelajar.

Sudibyo, A. (2019, February 12). Simalakama Digitalisasi untuk Media Jurnalistik: Opini Harian Kompas [Simalakama digitalization for journalistic media: Opinion of the Kompas Daily]. Kompas Daily, p. 4.

Syah, S. (2014). Membincang Pers, Kepala Negara dan Etika Media [Discussing the press, heads of state and media ethics]. Jakarta: Elex Media Komputindo.

Tribunnews.com. (2021). YouTube, Editor, YouTube, Producer, \& YouTube Inc. Youtube. Retrieved from https://www.youtube.com/results?search_query= tribunnews

VanWynsberghe, R., \& Khan, S. (2007). Redefining case study. International Journal of Qualitative Methods, 6(2), 80-94.

Yin, R. K. (2018). Case study research and applications: Design and methods (6th ed.). Thousand Oaks, CA: SAGE Publications, Inc.

Zakaria, N. F., \& Razak, F. H. A. (2018). The effect of Facebook on journalists in news writing. Journal of Media and Information Warfare, 11, 29-49.

\section{About the Authors}

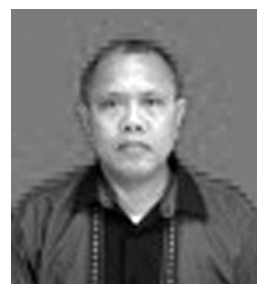

Muslikhin Muslikhin is a Doctoral Candidate at the Postgraduate School of Communication Science, Padjadjaran University, Indonesia. In addition, he is also a Permanent Lecturer and Head of the Broadcasting/Mass Communication Laboratory, Department of Communication Science, Faculty of Economics and Communication, Bina Nusantara University, Indonesia. Since 1994, he has been a Journalist on a private television station in Indonesia.

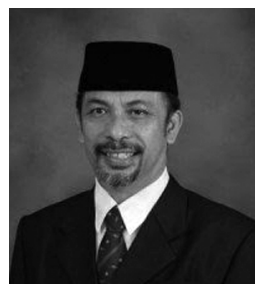

Deddy Mulyana is a Professor at the Faculty of Communication Sciences (Fikom) and the Postgraduate Program at Padjajaran University in Bandung, Indonesia, as well as a Non-Permanent Professor at the Postgraduate Program at the Bandung Institute of Technology (ITB), Indonesia. A Doctoral Graduate of Monash University, Australia (1996), who has wrote 30 books, he has been a Researcher and Visiting Professor at Northern Illinois University, US (2000-2001), Technische Universitat IImenau, Germany (2002-2005), Randolph-Macon Woman's College, Lynchburg, Virginia, US (2004), and Universiteit Leiden, the Netherlands (2005-2006).

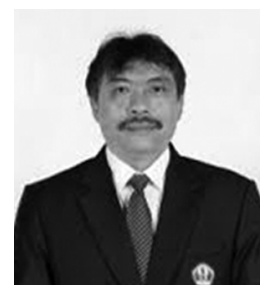

Dadang Rahmat Hidayat is a Lecturer at the Faculty of Communication Studies (Fikom), Padjadjaran University (Unpad) Bandung, Indonesia, with studies of journalism, ethics and regulation as well as political communication. He has been Dean of the Faculty of Communication (Fikom) Unpad (2016-2021). A Graduate of journalism and law, he also holds a Master's degree and a doctorate in Communication Science, all from Unpad. He was the Chairman of the Regional Indonesian Broadcasting Commission (KPID) West Java (2004-2010), Chairman of the Central Indonesian Broadcasting Commission (2010-2012). He was the General Chairperson of the Central Management of the Indonesian Bachelor of Communication Association (ISKI) for the 2017-2020 period, as well as a Member of the Central ASPIKOM Expert Council. 
Prahastiwi Utari is the Deputy Dean of the Faculty of Social and Political Sciences (FISIP) Solo State University (UNS), Central Java, Indonesia. She obtained her PhD degree from Communication and Media Arts, Newcastle University, Australia, in 2004. Lecturer of Communication Science at Postgraduate level for Master and Doctoral at UNS, Central Java, Indonesia. Prahastiwi Utari is also the Head of Teaching and Curriculum Division, Central Executive of the Association of Communication Colleges (ASPIKOM). 